\title{
Variation in physico-chemical properties of soil under different agri-horti system in Vindhyan region
}

\author{
Akankasha Ankita Ekka, Dileep Kumar*, Anand Prakash Singh and Awtar Singh \\ Department of Soil Science and Agricultural Chemistry, Institute of Agricultural Sciences, Banaras Hindu \\ University, Varanasi (U.P.), INDIA \\ *Present Address: Micro Nutrient Research Project (ICAR), Anand Agricultural University, Anand 388110 \\ (Gujarat) ,INDIA \\ *Corresponding author. E-mail: dileepdixit.bhu@gmail.com
}

Received: May 9, 2016; Revised received: December 6, 2016; Accepted: May 22, 2017

\begin{abstract}
Adoption of unsuitable production system may lead to deterioration of soil physico-chemical properties. Hence, it becomes important to assess the impact of various production systems. For this purpose, a study was carried out to find out variation in physico-chemical properties of soil in agri-horti system based four orchards of Rajiv Gandhi South Campus, Banaras Hindu University, Mirzapur, India. Soil samples were collected from the orchards of custard apple (Annona reticulate), guava (Psidium guajava), bael (Aegle marmelos) and crane berry (Carissa carandas) from two depths $(0-15$ and $15-30 \mathrm{~cm}$ ) separately within canopy and out of canopy of different plants. The results of the study revealed that all the agri-horti systems were effective in bringing gradual improvement in the physico-chemical properties of the soil. Among different orchards tried, the custard apple system resulted in the highest improvement in temperature $\left(27.16{ }^{\circ} \mathrm{C}\right)$, moisture $(24.53 \%)$ and water-holding capacity $(41.80 \%)$, whereas crane berry based system recorded better result in case of bulk density, porosity, electrical conductivity, $\mathrm{pH}$, organic carbon, available $\mathrm{N}\left(187.55 \mathrm{~kg} \mathrm{ha}^{-1}\right)$ and $\mathrm{K}\left(193.46 \mathrm{~kg} \mathrm{ha}^{-1}\right)$. Custard apple based system recorded highest DTPA extractable micronutrients (Zn 0.54, Fe 17.23, Cu 0.88 and Mn14.72 $\mathrm{mg} \mathrm{ka}^{-1}$ ).
\end{abstract}

Keywords: Agri-harti based orchard,Depth of soil, Physico-chemical properties of soil, Plant canopy

\section{INTRODUCTION}

Degradation of soil quality is one such issue which is often attributed to improper use of chemical fertilizers and pesticides. In India orchards are usually planted in low fertile soil, a number of reports highlighted the deficiency of major (nitrogen, phosphorous and potassium) and minor (zinc, copper, iron, manganese and boron) nutrients in the citrus orchards in different parts of the world (Sharif et al., 1998; Zia et al., 2006). According to Nair (1984), different systems like, agrihorticultural, agro-forestry and agri-pastoral systems have very much potential to minimize the loss of soil through erosion and runoff, and to sustain soil organic matter, improve soil physical properties and promote efficient nutrient cycling. The land use systems comprising of tree, crops and pastures play a vital role in improving soil fertility and its quality. Trees have capacity to change the properties of soil (Young, 1991). Past few decade there has been rising international interest in studies on the influence of trees on their surrounding environment (Eldridge and Wong 2005; Obrador and Moreno 2006). Orchard ground floor management systems are actually impacting the nutrient dynamics, hydraulic properties and productivity under short or long-term conditions (Rodrigues et al.,
2011). The Vindhayan soil of district Mirzapur in eastern Uttar Pradesh of India exhibit catenary's relationship with increase in drainage intensity down the slope, changes in colour from yellowish brown to reddish grey and texture from loam to clay or silt clay are observed. The $\mathrm{C} / \mathrm{N}$ ratio of the soil in the low lying areas was higher than in upland and terrace soils of sand stone-shale topo-sequences (Yadav et al., 1977). As one of the oldest geological formation of the country, Vindhayan system covers about $80-90 \%$ portion of the Mirzapur district of Uttar Pradesh. The Rajiv Gandhi South Campus, Banaras Hindu University has cultivable and non cultivable land. In this region, intercropping of cereal crops with custard apple, guava, crane berry, bael and aonla etc are more suitable under the agri-horti system. The present study was planned to identify the agri-horti system which could promote efficient nutrient recycling to achieve higher improvement in properties of red soils of Vindhyan region in Mirzapur district of India.

\section{MATERIALS AND METHODS}

Study area: Experiment was carried out at Rajiv Gandhi South Campus, of the Banaras Hindu University, India to evaluate the variations in physico-chemical 
properties of soil caused by four agri-horti systems which are six years old. The campus is occupying over an area of more than 1000 ha and it situated in Vindhyan region of district Mirzapur, India (25 $15^{\circ}$ ' latitude and $82^{\circ} 37^{\prime}$ longitude). This vindhyan region comes under agro-climatic zone III A (semi-arid eastern plain zone), rainfed condition and invariably poor fertility status of the soils. The climate is typically semi-arid, with low rainfall and moderate humidity.

Soil analysis: Soil samples were collected from the agri-horti based orchards of custard apple, guava, bael and crane berry from two depths (0-15 and $15-30 \mathrm{~cm})$ separately within canopy and out of canopy of different orchards. Green gram, mustard and pearl millet are taken as an inter cropping in different orchards. Collected soil sample were brought into laboratory, dried in shade at room temperature and processed to pass through 2-mm sieve. Soil temperature was recorded using mercury-in-glass thermometer capable of measuring temperature in the range of 0 to $50{ }^{\circ} \mathrm{C}$. (Nwankwo and Ogagarue, 2012). Water holding capacity of the soil samples was determined by KeenRoczkowski box as described by Chopra and Kanwar (1988). The soil samples were analysed for $\mathrm{pH}$ and EC in a 1:2.5 soil: water mixture (Jackson, 1973); organic carbon by a modified Walkley-Black method (Jackson, 1973); miniralizable $\mathrm{N}$ by potassium permanganate method (Subbiah and Asija, 1956); available P by Bray. and Kurtz 1954; available K in soil with flame photometer (Hanway and Heidal, 1969); available sulphur by the turbidimetric method (Chesnin and Yien, 1951) and DTPA extractable micronutrients ( $\mathrm{Zn}$, $\mathrm{Fe}, \mathrm{Mn}$ and $\mathrm{Cu}$ ) with AAS (Lindsay and Norvell, 1978).

Statistical analysis: The statistical analysis of the data was done by the analysis of variance (ANOVA) of factorial randomized block design. The means were tested for significance at $\mathrm{P} \leq 0.05$.

\section{RESULTS AND DISCUSSION}

\section{Effect on physical properties of soil}

Soil temperature: The temperature in custard apple, guava, bael, and crane berry soils were 27.16, 26.48, 27.12 and $26.18{ }^{\circ} \mathrm{C}$, respectively. The highest temperature $\left(27.16^{\circ} \mathrm{C}\right)$ was observed in custard apple orchard and lowest $\left(26.18{ }^{\circ} \mathrm{C}\right)$ in crane berry orchard. The mean value of soil temperature was observed to be $26.69{ }^{\circ} \mathrm{C}$ within canopy and $26.66{ }^{\circ} \mathrm{C}$ out of canopy. The temperature within canopy and out of canopy did not vary significantly. Differences in soil temperature are expected due to direct inhibition of incoming solar radiation by the tree canopy and also due to surface residues. Similar finding was also observed by Sharma, 2015. Further, the temperature was recorded in morning hours which was probably the reason behind non significant difference in soil temperature of within and outside of canopy. Fortin (1993) observed that surface residue cover can affect soil temperature by insulating the soil surface. The temperature observed at $15 \mathrm{~cm}$ depth was $26.27^{\circ} \mathrm{C}$ and at $30 \mathrm{~cm}$ depth, it was $27.20^{\circ} \mathrm{C}$.

Soil moisture: The value of soil moisture content that observed in custard apple, guava, bael and crane berry orchard were $24.53,20.90,21.27,21.83 \%$ respectively, and presented in Table 1. The highest soil moisture was observed in custard apple whereas lowest in guava orchard. Soil moisture within canopy was significantly higher $(23.66 \%)$ as compared to out of canopy (20.33 $\%)$. The higher soil moisture within canopy may be due to surface cover and shading effect of trees. Soil moisture content of $0-15 \mathrm{~cm}$ was recorded in lower value $(20.72 \%)$ as compared to $0-30 \mathrm{~cm}$ depth $(23.54$ $\%)$. This observation clearly shows that the soil moisture is increasing with increasing depth. Brady and Weil (2002) also reported that soil moisture increases with increase in depth. The greater soil moistureretention capacity of different agri-horti systems were attributed to incorporation of crop residues into the soil, which helped conserve the soil moisture and reduce the evaporation losses due to structural improvement (Kumar and Pandey 2004). Aulakh, and Baidwan (2004) reported that the soil moisture content variation was greater in fallow than in intercropping treatments, which is in conformity with the results of the present study.

Water holding capacity: The water-holding capacity of soil influences the availability of nutrients to the plants and promotes the root activities. Water holding capacity of soil samples collected from custard apple, guava, bael, and crane berry orchards were found to be $41.00,41.81,39.22$ and $40.76 \%$, respectively. Water holding capacity within canopy was observed to be $41.04 \%$ which was higher than that of out of canopy (40.30\%). Odewumi et al. (2013) also observed that the soil under teak canopy had relatively higher water holding capacity than soil outside teak soil canopy. However, it was of interest to observe that with the increase in the soil depths the water-holding capacity was found to decrease. Water holding capacity at 0-15 cm depth was $41.39 \%$ and at $15-30 \mathrm{~cm}$ depth it was $40.01 \%$. Gang et al. (2007) also observed that water holding capacity decreased with depth. The addition and recycling of biomass under intercropping systems help improve organic $\mathrm{C}$, soil structure, and soil aeration, thereby improving the physical, chemical, and biological environments of soil (Maheswarappa, 1998), which might be responsible for increase in the water-holding capacity of the soil. This is in accordance with the works of Aulakh and Baidwan (2004) and Kumar and Pandey (2004). According to Gupta (1983), continuous intercropping also reduces the bulk density of the soil and thereby improves the waterholding capacity of soil by reducing the percentage pore space, which is in the line of the present study. 
Bulk density: Among the different orchards of the agri -horti base systems, crane berry orchard recorded significantly better bulk density over custard apple, guava and bael orchards. It might be due to higher organic matter accumulation (Narain and Singh 1985). Significantly lower bulk density was also recorded under within canopy when compared to the samples collected from soil out of canopy. Odewumi et al. (2013) reported that the value of bulk density was slightly higher in soil outside tree canopy than in soil under tree canopy. The improvement in bulk density might be attributed to increase in the soil organic-matter content (Maheswarappa et al., 1998) brought about by the incorporation of the huge amount of biomass of the agrihorti based cropping system, which resulted in better aggregation properties of the soil. The bulk density of soil samples was found to be significantly lower at 0-15 cm depth than soil samples collected from 15-30 cm depth. According to Ahmed (2002), the bulk density increases with increasing depth. This might be due to more compaction of soil at lower depths.

Porosity: Significant variations were occurred in the porosity under various orchards. The highest porosity $(51.09 \%)$ of soil was recorded in custard apple orchards $50.01 \%$ whereas lowest $(50.01 \%)$ under crane berry orchard. The porosity of soil samples drawn from within canopy was $49.71 \%$ which was significantly higher under out of canopy. It was also observed that porosity at $15-30 \mathrm{~cm}(51.07 \%)$ which was significantly higher than $0-15 \mathrm{~cm}$ depth $(50.15 \%)$. However, Lipiec et al. (2005) reported that tillage practices decreased the soil porosity with increasing depth. Brady and Weil (2002) also observed that the decrease in organic matter shifts macro-pores to micro pores, thus the porosity was higher at $15-30 \mathrm{~cm}$ depth and at out of canopy.

\section{Effect on chemical properties of soil}

Soil pH and EC: The soil $\mathrm{pH}$ values of custard apple, guava, bael and crane berry orchards were 5.5, 5.6, 5.7 and 5.3 , respectively. The soil $\mathrm{pH}$ within canopy was recorded in lower than out of canopy. With increase the depth of soil from $0-15$ to $15-30 \mathrm{~cm}$ increased value of $\mathrm{pH}$. This might be due to leached down of soluble salts. Generally $\mathrm{pH}$ did not show any specific trend with depth but Kumar et al. (2012) reported an increase in soil $\mathrm{pH}$ with increasing depth of profiles which was due to prevention of leaching of soluble bases to the deeper zones of the soil. This is definitely an interesting development in soil reaction because soil $\mathrm{pH}$ was increased toward neutrality, which is a desirable factor for improvement of soil condition. This was due to the nitrification process in the soil, and addition of biomass of intercrops might have influenced the ionic exchange capacity of the soil, thus resulting in a slow increase in the soil $\mathrm{pH}$ toward the intermediate favorable range.

Higher electrical conductivity was recorded within canopy as compared to out of canopy. The electrical conductivity was also found higher under $15 \mathrm{~cm}$ of depth as compared to $30 \mathrm{~cm}$ depth. Fida et al. (2011) also reported higher electrical conductivity at subsurface. It might be due to leaching of salt from upper surface to lower surface. This shows that salinity did not have any harmful effect on crop growth. The increase in the soil organic-matter content and favorable changes in the soil physical, chemical, and biological environment increase the soil microorganism activities, which might have been favored to increase the electrical conductivity of the soil as reported by Maheswarappa et al. (1998) and Manna and Singh (2001). Aulakh and Baidwan (2004) also reported that intercropping systems resulted in greater electrical conduc-

Table 1. Physical properties of different orchards soils of Rajiv Gandhi South Campus, Mirzapur.

\begin{tabular}{|c|c|c|c|c|c|c|}
\hline Treatment & $\begin{array}{l}\text { Temperature } \\
\left({ }^{\circ} \mathrm{C}\right)\end{array}$ & $\begin{array}{l}\text { Moisture } \\
(\%)\end{array}$ & $\begin{array}{l}\text { Water holding } \\
\text { capacity }(\%)\end{array}$ & $\begin{array}{l}\text { Bulk density } \\
\left(\mathrm{Mg} \mathrm{m}^{-3}\right)\end{array}$ & $\begin{array}{l}\text { Particle density } \\
\left(\mathrm{Mg} \mathrm{m}^{-3}\right)\end{array}$ & $\begin{array}{l}\text { Porosity } \\
(\%)\end{array}$ \\
\hline \multicolumn{7}{|l|}{ Factor I Orchards } \\
\hline Custard Apple & 27.16 & 24.53 & 41.81 & 1.37 & 2.68 & 51.09 \\
\hline Guava & 26.48 & 20.90 & 41.00 & 1.35 & 2.67 & 50.75 \\
\hline Bael & 27.12 & 21.27 & 39.22 & 1.35 & 2.66 & 50.60 \\
\hline Crane berry & 26.18 & 21.83 & 40.76 & 1.33 & 2.65 & 50.01 \\
\hline $\mathrm{SEm} \pm$ & 0.39 & 1.00 & 0.70 & 0.01 & 0.003 & 0.23 \\
\hline $\operatorname{LSD}(\mathrm{P}=0.05)$ & NS & NS & NS & 0.02 & 0.01 & 0.66 \\
\hline \multicolumn{7}{|l|}{ Factor II Canopy } \\
\hline Within canopy & 26.69 & 23.66 & 41.04 & 1.31 & 2.64 & 49.71 \\
\hline Out of canopy & 26.66 & 20.33 & 40.30 & 1.38 & 2.68 & 51.41 \\
\hline $\mathrm{SEm} \pm$ & 0.28 & 0.71 & 0.49 & 0.005 & 0.002 & 0.16 \\
\hline $\operatorname{LSD}(\mathrm{P}=0.05)$ & NS & 2.04 & NS & 0.01 & 0.01 & 0.47 \\
\hline \multicolumn{7}{|c|}{ Factor III Depth of soil sampling } \\
\hline $0-15 \mathrm{~cm}$ & 26.27 & 20.72 & 41.39 & 1.33 & 2.65 & 50.15 \\
\hline $15-30 \mathrm{~cm}$ & 27.20 & 23.54 & 40.01 & 1.37 & 2.67 & 51.07 \\
\hline $\mathrm{SEm} \pm$ & 0.28 & 0.71 & 0.49 & 0.005 & 0.002 & 0.16 \\
\hline $\operatorname{LSD}(\mathrm{P}=0.05)$ & 0.80 & 2.04 & NS & 0.01 & 0.01 & 0.47 \\
\hline \multicolumn{7}{|l|}{ Interaction } \\
\hline Orchard $\times$ Canopy & NS & $\mathrm{S}$ & NS & $\mathrm{S}$ & $\mathrm{S}$ & S \\
\hline
\end{tabular}


Table 2. Chemical properties of different orchards soils of Rajiv Gandhi South Campus, Mirzapur.

\begin{tabular}{|c|c|c|c|c|c|c|}
\hline Treatment & pH & $E C\left(d S m^{-1}\right)$ & OC (\%) & Nitrogen $\left(\mathrm{kg} \mathrm{ha}^{-1}\right)$ & Phosphorous $\left(\mathrm{kg} \mathrm{ha}^{-1}\right)$ & Potassium $\left(\mathrm{kg} \mathrm{ha}^{-1}\right)$ \\
\hline \multicolumn{7}{|l|}{ Factor I Orchards } \\
\hline Custard Apple & 5.5 & 0.380 & 0.44 & 171.44 & 9.60 & 191.04 \\
\hline Guava & 5.6 & 0.400 & 0.47 & 180.51 & 9.57 & 184.94 \\
\hline Bael & 5.7 & 0.440 & 0.49 & 182.76 & 10.38 & 180.31 \\
\hline Crane berry & 5.3 & 0.410 & 0.54 & 187.55 & 9.49 & 193.46 \\
\hline $\mathrm{SEm} \pm$ & 0.13 & 0.020 & 0.01 & 2.66 & 0.36 & 1.70 \\
\hline $\operatorname{LSD}(\mathrm{P}=0.05)$ & NS & NS & 0.02 & 7.67 & NS & 4.89 \\
\hline \multicolumn{7}{|l|}{ Factor II Canopy } \\
\hline Within canopy & 5.5 & 0.430 & 0.54 & 191.75 & 9.80 & 191.28 \\
\hline Out of canopy & 5.6 & 0.390 & 0.44 & 170.52 & 9.78 & 183.35 \\
\hline $\mathrm{SEm} \pm$ & 0.09 & 0.020 & 0.01 & 1.88 & 0.25 & 1.20 \\
\hline $\operatorname{LSD}(\mathrm{P}=0.05)$ & NS & NS & 0.01 & 5.42 & NS & 3.46 \\
\hline \multicolumn{7}{|c|}{ Factor III Depth of soil sampling } \\
\hline $0-15 \mathrm{~cm}$ & 5.3 & 0.400 & 0.50 & 186.12 & 11.20 & 189.50 \\
\hline $15-30 \mathrm{~cm}$ & 5.7 & 0.420 & 0.46 & 175.01 & 8.32 & 185.38 \\
\hline $\mathrm{SEm} \pm$ & 0.09 & 0.020 & 0.01 & 1.88 & 0.25 & 1.20 \\
\hline $\operatorname{LSD}(\mathrm{P}=0.05)$ & 0.27 & NS & 0.01 & 5.42 & 0.73 & 3.46 \\
\hline \multicolumn{7}{|l|}{ Interaction } \\
\hline Orchard $\times$ Canopy & NS & NS & $\mathrm{S}$ & $\mathrm{S}$ & NS & $\mathrm{S}$ \\
\hline
\end{tabular}

tivity.

Soil organic carbon: Organic carbon content of the soil samples collected from orchards of custard apple, guava, bael, and crane berry was $0.44,0.47,0.49$ and $0.54 \%$, respectively. The highest organic carbon was found in crane berry orchard and least in guava orchard. Within canopy, organic carbon was high due to plant leaf residues as compared to out of canopy. The organic carbon was found to be higher at $0-15 \mathrm{~cm}$ depth $(0.50 \%)$ which was significantly lower at $15-30$ $\mathrm{cm}$ depth. Similar result was reported by Gregorich et al. (1995). The existence of low to medium organic carbon content of soil was might be due to reviling climatic condition-(high temperature) and poor management (Ghuge et al, 2002). The increase in organic $\mathrm{C}$ content of soil under these agri-horti systems might be due to the decomposition of biomass of different inter crops. Similar findings on increase in organic C contents of orchard soil due to intercropping practices in mango orchard have been reported by Nath et al. (2003), Aulakh and Baidwan (2004), and Swain and Patro (2007).

Available nitrogen: Significantly highest available nitrogen content in soil $\left(187.55 \mathrm{~kg} \mathrm{ha}^{-1}\right)$ was observed in crane berry orchard whereas lowest under custard apple orchard $\left(171.44 \mathrm{~kg} \mathrm{ha}^{-1}\right)$. Nitrogen content within canopy was significantly higher $\left(191.75 \mathrm{~kg} \mathrm{ha}^{-1}\right)$ as compared to out of canopy $\left(170.52 \mathrm{~kg} \mathrm{ha}^{-1}\right)$. It might be due to higher accumulation of organic carbon within the canopy. The improvement in available $\mathrm{N}$ content of the soil under canopy might also be due to fixation of atmospheric $\mathrm{N}$ through increased enzymatic and microbial activity in the rhizosphere by the inter crops and release of bound nutrient after their decomposition in the soil. Similar results of increased available N content of the soil through intercropping in mango orchard have been reported by Kumar and Pandey (2004) and Swain and Patro (2007). Mengel and Kirkby (1987);

Table 3. Chemical properties of different orchards soils of Rajiv Gandhi South Campus, Mirzapur.

\begin{tabular}{|c|c|c|c|c|c|}
\hline Treatment & Sulphur (mg kg $\left.{ }^{-1}\right)$ & Zinc $\left(\mathrm{mg} \mathrm{kg}^{-1}\right)$ & Iron $\left(\mathrm{mg} \mathrm{kg}^{-1}\right)$ & Copper (mg kg $\left.{ }^{-1}\right)$ & Manganese $\left(\mathrm{mg} \mathrm{kg}^{-1}\right)$ \\
\hline \multicolumn{6}{|c|}{ Factor I Orchards } \\
\hline Custard Apple & 7.37 & 0.54 & 17.23 & 0.88 & 14.72 \\
\hline Guava & 8.03 & 0.51 & 14.76 & 0.57 & 14.10 \\
\hline Bael & 8.09 & 0.47 & 13.20 & 0.64 & 13.61 \\
\hline Crane berry & 7.86 & 0.53 & 13.88 & 0.55 & 13.52 \\
\hline $\mathrm{SEm} \pm$ & 0.25 & 0.02 & 0.99 & 0.08 & 1.08 \\
\hline $\operatorname{LSD}(\mathrm{P}=0.05)$ & NS & NS & 2.86 & 0.24 & NS \\
\hline \multicolumn{6}{|c|}{ Factor II Canopy } \\
\hline Within canopy & 8.02 & 0.51 & 15.37 & 0.73 & 14.65 \\
\hline Out of canopy & 7.72 & 0.52 & 13.64 & 0.55 & 13.37 \\
\hline $\mathrm{SEm} \pm$ & 0.17 & 0.02 & 0.70 & 0.06 & 0.77 \\
\hline $\operatorname{LSD}(\mathrm{P}=0.05)$ & NS & NS & 2.02 & 0.17 & NS \\
\hline \multicolumn{6}{|c|}{ Factor III Depth of soil sampling } \\
\hline $0-15 \mathrm{~cm}$ & 8.02 & 0.53 & 17.07 & 0.72 & 16.16 \\
\hline $15-30 \mathrm{~cm}$ & 7.66 & 0.49 & 12.46 & 0.60 & 11.81 \\
\hline $\mathrm{SEm} \pm$ & 0.17 & 0.02 & 0.70 & 0.06 & 0.77 \\
\hline $\operatorname{LSD}(\mathrm{P}=0.05)$ & NS & NS & 2.02 & NS & 2.21 \\
\hline
\end{tabular}


and Tisdale et al. (1995) also reported that total $\mathrm{N}$ content of a soil is directly associated with its organic carbon content. In the present study it was interesting to observe that the $\mathrm{N}$ content of each intercropped plot decreased with the soil depth. Nitrogen content at 0-15 and $15-30 \mathrm{~cm}$ depth was $186.12 \mathrm{~kg} \mathrm{ha}^{-1}$ and $175.01 \mathrm{~kg}$ $\mathrm{ha}^{-1}$, respectively, which might be due to lower leaching losses as reported by Sharma and Choudhury (2007).

Available phosphorus: The available phosphorous content in soil samples of custard apple, bael, guava and crane berry orchard was 9.60, 9.57, 10.38 and 9.49 $\mathrm{kg} \mathrm{ha}^{-1}$, respectively. The Significant Highest value of available phosphorus $\left(10.38 \mathrm{~kg} \mathrm{ha}^{-1}\right)$ was observed in bael orchard whereas lowest $\left(9.49 \mathrm{~kg} \mathrm{ha}^{-1}\right)$ in crane berry orchard. The increase in the availability of $\mathrm{P}$ content in the soil by different agri-horti based orchard might be due to increase in the total microflora population, particularly $\mathrm{P}$ solublizers in the rhizosphere of plant, which is in line with the findings of Varghese and Balakrishnan (1978). Phosphorus content is soil of within canopy and out of canopy did not vary significantly. Watanab and Olsen (1965) also reported that P in soil was high in surface soil, which could be attributed to the applied phosphatic fertilizers or higher organic matter. Phosphorus content at $0-15 \mathrm{~cm}$ depth was $11.20 \mathrm{~kg} \mathrm{ha}^{-1}$ and at $15-30 \mathrm{~cm}$ depth it was $8.32 \mathrm{~kg}$ $\mathrm{ha}^{-1}$ but the effect was non significant. Mehvish et al. (2011) also observed higher $P$ concentration in the surface soils which decreased gradually with increasing soil depth.

Available potassium: The average potassium content of custard apple, bael, guava and crane berry orchards soil were $191.04184 .94,180.31$ and $193.46 \mathrm{~kg} \mathrm{ha}^{-1}$ respectively. Significantly highest potassium was recorded in crane berry orchard (193.46 $\left.\mathrm{kg} \mathrm{ha}^{-1}\right)$ whereas lowest potassium content in soil was under bael orchard $\left(180.31 \mathrm{~kg} \mathrm{ha}^{-1}\right)$. This corroborates with the findings of Swain and Patro (2007). The increase in availability of $\mathrm{K}$ contents in the soil might be due to increase in humus content of soil after decomposition of biomass of intercrops that builds up total population of beneficial microbes in the orchard soil. Similar results of improvement in nutrient status of soil due to intercropping have been reported by Maheswarappa et al. (1998), Kumar and Pandey (2004), and Swain and Patro (2006). The higher potassium content was observed from sample drawn from within canopy (191.28 $\left.\mathrm{kg} \mathrm{ha}^{-1}\right)$ and lower in out of canopy $\left(183.35 \mathrm{~kg} \mathrm{ha}^{-1}\right)$. High potassium within canopy may be due to high organic carbon. Padmaja and Singh (1999) also observed a significant positive correlation between available forms of potassium and organic carbon and silt content of soil. The potassium in $15 \mathrm{~cm}$ depth of soil was significantly higher than $30 \mathrm{~cm}$ depth. Higher available $\mathrm{K}$ in surface soils could be attributed to more intensive weathering, release of labile- $\mathrm{K}$ from organic residues of cultivated crop plants and upward translocation of $\mathrm{K}$ from depths along with capillary rise of ground water which is stated by Pulakeshi et al. 2012.

Available sulphur: Sulphur content in soil of custard apple, bael, guava and crane berry orchards are 7.37, $8.09,8.03$ and, $7.86 \mathrm{mg} \mathrm{kg}^{-1}$, respectively. The highest $\mathrm{S}$ content was recorded in bale orchard. The sulphur content within canopy was higher than out of canopy. It was also noticed that available sulphur content at 15 $\mathrm{cm}$ depth was higher than $30 \mathrm{~cm}$ depth. Among the all treatments the effect was found to be non significant. Kumar et al. (2009) also reported that available sulphur content in red soil decreased with increased soil depth.

Available iron: The average available iron in custard apple, guava, bael and crane berry orchards soil was $17.23,14.76,13.20$ and $13.88 \mathrm{mg} \mathrm{kg}^{-1}$ respectively. Among the different orchards, custard apple recorded significantly highest iron content over rest of the orchards. The iron content was significantly higher within canopy $\left(15.37 \mathrm{mg} \mathrm{kg}^{-1}\right)$ with compare to out of canopy; it may be due to presence organic matter in soil. Sarkar et al. (2000) also found that the availability of iron increased significantly with increase in organic carbon. Iron content in soil at $15 \mathrm{~cm}$ depth was also found significantly higher $\left(17.07 \mathrm{mg} \mathrm{kg}^{-1}\right)$ than in 30 $\mathrm{cm}$ depth of soil $\left(12.46 \mathrm{mg} \mathrm{kg}{ }^{-1}\right)$. These dynamisms indicated the fact that optimum soil moisture levels have immense impact on the availability of micronutrients within soil profile. The iron content in all the soil samples collected from orchard lies under high range. This might be due to presence of iron oxide in red soil of the region.

Available zinc: Average zinc content in orchards of custard apple, guava, bael and crane berry was recorded $0.51,0.54,0.47$ and $0.53 \mathrm{mg} \mathrm{kg}^{-1}$ respectively. The highest $\mathrm{Zn}$ content in soil was found under custard apple orchard. It has been observed that zinc content in soil within canopy was found less than out of canopy but the difference found to be non significant. Sample collected from different depth of soil also recorded non significant difference in $\mathrm{Zn}$ content in soil. The highest $\mathrm{Zn}$ content in soil $\left(0.53 \mathrm{mg} \mathrm{kg}^{-1}\right)$ was observed at $15 \mathrm{~cm}$ depth of soil as compare to $30 \mathrm{~cm}$ depth of soil (0.49 mg kg-1). Bassirani et al. (2011) also observed that available $\mathrm{Zn}$ content in soil was found in decreasing trend with increasing depth. Zinc concentration in all the orchards was found to under deficiencies range. The main reasons for the deficiencies of zinc may be attributed to nature of parent material, coarse soil texture, low use of organic matter and micronutrient fertilizers of our soils.

Available copper: The mean value of copper content in soil of custard apple, guava, bael and crane berry orchard was observed $0.88,0.75,0.64$ and $0.55 \mathrm{mg} \mathrm{kg}^{-}$ ${ }^{1}$, respectively. The highest copper content was observed in custard apple orchard whereas the lowest in 
crane berry orchard. Within canopy, copper content was significantly higher $\left(0.73 \mathrm{mg} \mathrm{kg}^{-1}\right)$ than out of canopy $\left(0.55 \mathrm{mg} \mathrm{kg}^{-1}\right)$. High values of $\mathrm{Cu}$ might be due to relatively high organic matter content of soil. Within the vertical depth distributions, higher $\mathrm{Cu}$ concentrations were recorded at $15 \mathrm{~cm}$ depth of soil $(0.72$ $\left.\mathrm{mg} \mathrm{kg}^{-1}\right)$ as compared to $30 \mathrm{~cm}$ depth of soil $(0.60 \mathrm{mg}$ $\mathrm{kg}^{-1}$ ) but the difference was found to be non significant.. Sharma and Chaudhary (2007) also reported that surface horizons found higher copper content in soil and decreased with depth of soils.

Available manganese: Average available manganese content in the soil of the four orchards custard apple, guava, bael and crane berry was 14.10, 14.72, 13.61 and $13.52 \mathrm{mg} \mathrm{kg}^{-1}$ respectively. The manganese content within canopy $\left(14.65 \mathrm{mg} \mathrm{kg}^{-1}\right)$ was higher than that of out of canopy $\left(13.37 \mathrm{mg} \mathrm{kg}^{-1}\right)$. The manganese content at $0-15 \mathrm{~cm}$ depth was also found to be significant higher (16.16 $\mathrm{mg} \mathrm{kg}^{-1}$ ) than $15-30 \mathrm{~cm}$. depth (11.81 $\left.\mathrm{mg} \mathrm{kg}^{-1}\right)$. Sharma et al. (2003) also observed that DTPA extractable Mn was positively and significantly influenced by the organic carbon.

\section{Conclusion}

Among four orchards, custer apple system produced the most improvement in temperature $\left(27.16{ }^{\circ} \mathrm{C}\right)$, moisture $(24.53 \%)$ and water-holding capacity (41.80 $\%$ ) whereas crane berry based system recorded better result in bulk density, particle density, porosity, electrical conductivity, $\mathrm{pH}$ and organic carbon content, The nutrients status under different orchards was also enhanced availability of major and micronutrients ( $\mathrm{Zn}$ 0.54, Fe 17.23, $\mathrm{Cu} 0.88$ and Mn14.72 $\mathrm{mg} \mathrm{ka}^{-1}$ ) in soil. Hence, use of different agri-horti based models could be best options to overcome the problems of ecological imbalance for sustainable crop production.

\section{REFERENCES}

Ahmed, H. (2002). Assessment of spatial variability of some physicochemical properties of soils under different elevations and land use systems in the western slopes of Mount Chilalo, Arsi. M.Sc. Thesis Submitted to the School of Graduate Studies, Alemaya University, Ethiopia. $111 \mathrm{p}$

Aulakh, P. S., Vij, V. K. and Baidwan R. P. S. (2004). Studies on the effects of intercrop biomass on soil and tree health of Kinnow Mandarin. New Delhi: Indian Society of Horticulture.

Bassirani, N., Abolhassani, M. and Galavi, M. (2011). Distribution of available micronutrients as related to the soil characteristics of Hissar; Haryana (India). African J. of Agric. Res., 6(18): 4239-4242

Brady, N. C. and Weil, R. R. (2002). The nature and properties of soils, $13^{\text {th }}$ Ed. Prentice- Hall Inc., New Jersey, USA. $960 \mathrm{p}$

Bray, R. H. and Kurtz, L. T. (1954). Determination of total organic and available forms of phosphorous in soil. Soil science. 59: 39-45.
Chesnin, L. and Yien, C. H. (1951). Turbidimetric determination of available sulphur. Proceeding of Soil Sci. of America, 15: 149-151

Chopra, S. L. and Kanwar, J. S. (1988). Analytic Agriculture Chemistry, Kalyani Publishers, New Delhi.

Eldridge, D. and Wong, V. (2005). Clumped and isolated trees influence soil nutrient levels in an Australian temperate box woodland. Plant \& Soil, 270: 331-342

Fida, M., Khan, S., Razzaq, A., Nawaz, I. and Izhar-ul-Haq (2011). Fertility status of guava orchards in Kohat district of Pakistan. J. of Soil Sci. and Environ. Manag., 3 (9): 260-269.

Fortin, M. C. (1993). Soil temperature, soil water and no-till corn development following in-row residue removal. Agronomy J., 85: 571-576

Gang, L. X., Li , F., Min, Z. R., Yan, Z. Z. and Singh, B. (2007). Soil physical properties and their relations to organic carbon pools as affected by land use in an alpine pastureland. CAB Abstracts Geoderma, 139(1/2): 98105

Ghuge, S. D. (2002). Fertility status of sugarcane growing soils under Balaghat Shetkari Co--operative sugar factory Ujana. M.Sc. (Agri.) Thesis submitted to M.K.V., Parbhani.

Gregorich, E. G., Ellert, B. H. and Monreal, C. M. (1995). Turnover of soil organic matter and storage of corn residue carbon estimated from natural $13 \mathrm{C}$ abundance. Canadian J. of Soil Sci., 75: 161-164

Gupta, J. P. (1983). Soil and moisture conservation for increasing crop production in arid lands. Annual report. Jodhpur, India: CAZRI.

Hanway, J. J. and Heidel, H. (1969). Soil analysis method as used in Iowa State, College and Soil Testing Laboratory. Iowa Agriculture. Bulletin, 57: 1-131

Jackson, M. L. (1973). Soil Chemical Analysis. Prentice Hall of India Pvt. Ltd., New Delhi.

Kumar, D. and Pandey, V. (2004). A short note on vegetative growth of Aonla as influenced by intercrops under rainfed conditions of Agra. Orissa J. of horti., 32 (2): 109111

Kumar, D., Singh S. and Kumar, P. (2009). Forms of sulphurin some soils of Mirzapur district of Uttar Pradesh. $J$. of Res. (BAU), 21(2): 115-121

Kumar, R., Rawat, K. S. and Yadav, B. (2012). Vertical, distribution of physico-chemical properties under different Topo-sequence in soil of Jharkhand. J. of Agri. Physics, 12(1): 63-69

Lindsay, W. L. and Norvell, W. A. (1978). Development of DTPA soil test for zinc, iron, manganese and copper". Soil Sci. Soci. of Amer., J.42: 421-428

Lipiec, J., Kus, J., Ska-Jurkiewicz, A. S. and Nosalewicz, A. (2005). Soil porosity and water infiltration as influenced by tillage methods. Soil and Till. Res., 89(2): 210-220

Maheswarappa, H. P., Hegda, M. B., Dhanapal, R. and Biddappa. C. (1998). Mixed forming in coconut garden: Its impact on soil physical, chemical properties, coconut nutrition, and yield. J.of Plant. Crops, 26 (2): 39-143

Manna, M. C. and Singh. M. V. (2001). Long-term effects of intercropping and biolitter recycling on soil biological activity and fertility status of subtropical soils. Bioresource Tech., 76 (2): 143-150

Mehvish, F., Khan, S., Razzaq, A., Nawaz, I. and Izhar-ulHaq (2011).Fertility status of guava orchards in Kohat 
District of Pakistan. J. of Soil Sci. and Environ. Manage., 3(9): 260-268

Mengel, K. and Kirkby, E. A. (1987). Principles of plant nutrition. Panima Publication Corporation, New Delhi, Bangalore, India. 687p

Nair, P. K. R. (1984). Role of trees in soil productivity and conservation. Soil productivity aspects of agro-forestry. The International Council for Research in AgroForestry. Nairobi, Pp. 85

Narain, P. and Singh, R. (1985). Indian For., I 11: 230-239. Production. John Wiley \& Sons, Inc., U.S.A. Malabar, Florida. $413 \mathrm{p}$

Nath, V. B., Das, M., Rai, P., Dey, Kumar, S. and Kumar, M. (2003). Mango-based cropping system for uplands of subhumid plateau region of eastern India. Progressive Horti., 35 (2): 142-145

Nwankwo, C. and Ogagarue, D. (2012). An Investigation of Temperature Variation at Soil Depths in Parts of Southern Nigeria. Ameri. J. of Environ. Engin., 2(5): 142-147

Obrador, J. J. and Moreno, G. (2006). Soil nutrient status and forage yield at varying distances from trees in four dehesas in Extremadura, Spain. In 'Silvopastoralism and Sustainable Land Management: International Congress on Silvopastoralism and Sustainable Management Held in Lugo, Spain April 2004'. (Eds MR Mosquera-Losada, A Riguero-Rodriguez, J McAdam) pp. 278-280. (CABI Publishing: Oxfordshire, UK) of Soil Science (IInd Ed.) ISBN 81-903797-4-7.pp 317-328

Odewumi, S. G., Iwara, A. I. and Ogundele, F. O. (2013). Effects of teak (Tectona grandis) cultivation on soil physical and chemical properties in Ajibode community, Ibadan, Oyo state. 1 Dept. of Geography and Planning, Lagos State University, Nigeria 2 Dept. of Geography, University of Ibadan, Nigeria.

Padmaja, G. and Singh, R. A. (1999). Status of potassium found in Alfisols of southern Telangana zone Of Andhra Pradesh. J. of Potassium Res., 15(1/4): 25

Pulakeshi, H. B. P., Patil, P. L., Dasog, G. S., Radder, B. M., Bidari, B. I. and Mansur, C. P. (2012). Mapping of nutrient status by geographic information system (GIS) in Mantagani village under northern transition zone of Karnataka. Karnataka J.of Agri. Sci., 25(3): 332-335

Rodrigues, M. Â., Lopes, J. I. Pavão, F. M., Cabanas, J. E. and Arrobas, M. (2011). Effect of soil management on olive yield and nutritional status of trees in rainfed orchards. Communi. Soil Sci. and Plant Anal., 42: 9931007

Sarkar, D., Haldar, A., Majumdar A. and Velayntham, M. (2000). Distribution of micronutrient cations in some Inceptisols and Entisols of Madhubani district of Bihar. $J$. of the Indian Soci. of Soil Sci., 48: 202-205

Sharif, M., Qayyum, A. and Khattak, J. K. (1998). Nutrients status of citrus orchard soil in Swat vally. Sarhad J. of Agri., 14 (3): 241-247

Sharma, C. (2015). Physico-Chemical Properties of Soils with Special Reference to Organic Carbon Stock under Different Land Use Systems in Dimoria Tribal Belt of Assam. J. of Agri. and Veteri. Sci., 8 (3): 32-36

Sharma, J. C. and Chaudhary, S. K. (2007). Vertical distribution of micronutrient cations in relation to soil characteristics in lower shiwaliks of solan in North-west Himalayas. J. of the Indian Soci. of Soil Sci., 55: 40-44

Sharma, R. P., Singh, M. and Sharma, J. P. (2003). Correlation studies on micronutrients vis-à-vis soil properties in some soils of Nagaur district in semi-arid region of Rajasthan. J. of the Indian Soci.of Soil Sci., 51(4): 522527

Subbiah, B. V. and Asija, G. L. (1956). A rapid procedure for estimation of nitrogen in soils. Current Scie., 25: 259-260

Swain, S. C. and Patro, L. (2006). Intercropping in guava orchard: A holistic farming system approach for sustainable development of environment and society. In Proceedings of the National Conference on Biodiversity Conservation for Sustainable Society, eds. K. Mishra and S. K. Palita, 78-83. Nayagarh, Orissa: Nayagarh College.

Swain, S. C. and. Patro, L. (2007). Horticulture-based cropping system: A strategy for sustainable development in rainfed upland. In Environmental hazards, ed. L. Patro and S. N. Tripathy, 44-69. New Delhi: Sonali.

Tisdale, S. L., Nelson, W. L., Beaton, J. D. and Havlin, J. L. (1995) Soil fertility and fertilizer, $5^{\text {th }}$ Ed. Prentice-Hall of India, New Delhi. 684 p

Varghese, P. T., Nelliat, E. V. and Balakrishnan, T. K. (1978). Beneficial interactions of coconut-cocoa crop combination. In Proceedings of the First Symposium on Plantation Crops, ed. E. V. Nelliat, V. Ranganathan, S. Vishveswara, S. N. Potti, and P. K. Zachariah, 383392. Kasaragod, India: Placrosum.

Watanab, F. S. and Olsen, S. R. (1965). Test of an ascorbic acid method for determination phosphorus in water $\mathrm{NaHCO}_{3}$ extract from soil. Soil Sci. Soci. of Ameri.proceeding., 29: 677-678

Yadav, B. R. Gupta, R. N. and Singh, B. D. (1977). Catanary relationship existing among the soil of lower vindhyan plateau in (U. P.). J. of the Indian Soci. of Soil Sci., 25: 253-257

Young, A. (1991). Soil fertility. In: Biophysical Research for Asian Agroforestry (M. E. Avery, M. G. R. Cannel, and C. K. Ong Eds). Winrock International USA and South Asia Books, USA. Pp. 187-208

Zia, M. J., Ahmad, R., Khaliq, I., Ahmad, A. and Irshad, M. (2006). Micronutrient status and management in orchard soil: applied aspects. Soil Environment,25(1):6-16 